\title{
IMPACT OF VALUE PERCEPTIONS ON LUXURY PURCHASE INTENTIONS: MODERATING ROLE OF CONSUMER KNOWLEDGE
}

\author{
DOI: 10.17261/Pressacademia.2018.855 \\ PAP- V.7-2018(8)-p.52-56
}

\section{Aysel Ercis ${ }^{1}$, Bilal Celik ${ }^{2}$}

${ }^{1}$ Ataturk University, Faculty of Economics and Administrative Sciences Department of Business Administration, Erzurum, Turkey. ayselercis@atauni.edu.tr, ORCID: 0000-0002-9835-8574

${ }^{2}$ Bayburt University, Faculty of Economics and Administrative Sciences Department of Business Administration, Bayburt, Turkey. bcelik@bayburt.edu.tr, ORCID: 0000-0001-6253-3177

\section{To cite this document}

Ercis, A., Celik, B. (2018). Impact of value perceptions on luxury purchase intentions: moderating role of consumer knowledge. PressAcademia Procedia (PAP), V.7, p.52-56.

Permemant link to this document: http://doi.org/10.17261/Pressacademia.2018.855

Copyright: Published by PressAcademia and limited licenced re-use rights only.

\begin{abstract}
Purpose- The purpose of this paper is to understand how value perceptions affect consumer luxury purchase intentions and how consumer knowledge moderate the relationships between consumer value perceptions and luxury purchase intentions.

Methodology- The authors use data from a survey of 271 consumers in Bursa and structural equation modelling (SEM) was used in order to analyse the data.

Findings- The results revealed that social, personal and functional value perceptions affect consumer luxury purchase intention. It is also show that consumer knowledge has a moderation effect on the relationships between personal and functional vale perceptions and luxury purchase intentions. However, consumer knowledge has not a moderation effect on the relationships between social value perceptions and luxury purchase intentions.

Conclusion- It is importamt for marketer to take into account value and value perceptions and so they ought to try to understand value and consumers' value perceptions.
\end{abstract}

Keywords: Luxury, value perceptions, consumer knowledge, purchase intentions.

JEL Codes: M30, M31

\section{INTRODUCTION}

The concept of "luxury" has been discussed for a long time. No one has fully identified yet, although the luxury has been identified by researchers. It was defined as "refined enjoyment, of elegance, of things desirable but not essential" (Goody, 2006, p. 341). When it comes to the definition of products, according to Shukla and Chattalas (2015) has defined luxury products as leading to pleasure and comfort and it also difficult in order to acquire. According to Nueno and Quelch (1998) certain characteristics of luxury brands includes six dimensions namely; premium quality, very high price, scarcity and uniqueness, aesthetics and polysensuality, ancestral heritage and personal history, super-fluousness. Moreover, the semiotics of the word luxury, its sociological references and the pragmatics of luxury brand management have been explained by (Kapferer, 1997). "Luxury defines beauty; it is art applied to functional items. Like light, luxury is enlightening. [...] They offer more than mere objects: they provide reference of good taste. That is why luxury management should not only depend on customer expectations: luxury brands are animated by their internal programme, their global vision, the specific taste which they promote as well as the pursuit of their own standards. [...] Luxury items provide extra pleasure and flatter all senses at once. [...] Luxury is the appanage of the ruling classes." (Kapferer 1997, P.253) Moving from these explanations, there is an agreement on the definition of luxury goods which provide esteem on the owner in addition to functional utility (Vigneron and Johnson, 2004). luxury goods provides consumers to satisfy in terms of not only socio-psychological but functional needs as well (Chattalas and Shukla, 2015; Shukla, 2012; Wiedmann et al., 2007; Hennigs et al., 2012). The term "value" has been defined as an overall evaluation of subjective worth of a product or a service considering all relevant evaluative criteria (Zeithaml, 1988). Moreover, some research explained that the value includes some fundamental dimensions namely functional, personal and social perceptions (Shukla and Purani, 2011; Tynan et al., 2010; Vigneron and Johnson, 2004; Wiedmann et al., 2009). Thus, the purpose of this paper is to develop and test a model which measures the impact of value perceptions on luxury purchase intentions and the moderating role of consumer knowledge.

\section{LITERATURE REVIEW}

In this section, the influence of value perception on luxury purchase intentions will be discussed according to the three underlying dimensions of value namely; social, personal and functional (Chattalas and Shukla, 2015) and the moderating role of consumer knowledge on luxury purchase intentions will be discussed. Furthermore, the proposed model and hypotheses will also be examined via use of 
structural equation modelling (SEM) regarding the value perception on luxury purchase intentions. As, it will enable us to identify the magnitude of the effects of value perceptions in the presence of other constructs (Chattalas and Shukla, 2015).

\subsection{Social Value Perceptions}

The meaning of products is important for consumers and their social group members and thus consumer in general purchase products in accordance with the what they mean for them and their social reference groups (Chattalas and Shukla, 2015; Wiedmann et al., 2007, 2009). In that point, "their behaviour is subject to pressures of social norms and expectations of socialisation-oriented institutions such as those arising from family and other reference groups (Shukla, 2012). As Kapferer (1997) observes, the history of luxury consumption is deeply rooted in the notion of social stratification" (Chattalas and Shukla, 2015). Also, many motivating forces affect consumer behaviour in order to buy and consumption of goods, one of the most important motivations for consumers to buy and consumption is to gain status or social prestige (Chattalas and Shukla, 2015; Shukla, 2010). In this sense, consumers use luxury goods in order to communicate prestige and social status apart from any functional benefits of luxury (Zhan and He, 2011). Researchers have carried out on the basis of Bourne (1957) work in the early 1980s and these researchers have focused on the reference group's effects on the luxury brands consumption (Wiedmann et al, 2007; Mason 1981 and 1992; Bearden and Etzel 1982). According to these studies, the reference group has effects on the conspicuous consumption of a product (Wiedmann et al, 2007). As an example of this, conspicuous consumption indicates wasteful consumption activities and leisure time activities, and the main reason behind conspicuous consumption is to show one's membership of a superior social class (Patsiaouras and Fitchett, 2012). Moreover, individuals tend to display their goods and seek for sign of social status (Souiden, M'Saad and Pons, 2011; Singh 1995 cited in Chaudhuri and Majumdar 2006). it can be hypothesized that;

H1: Social value perceptions are related to attitude toward luxury products

\subsection{Personal Value Perceptions}

There is an increasing in the consumption of luxury brands and consumers prefer to consume luxury brands for their symbolic benefits and hedonic experience and "personal motive oriented consumers are concerned with being able to identify their internal self with the product, gain an enjoyable experience from the product and match their individual tastes to the product's image (Shukla, 2012; Wong and Ahuvia, 1998). Personal motive oriented consumers focus on hedonistic value and self-awareness rather than other expectations of consumption (Shukla, 2012; Tsai, 2005). These kinds of consumptions that has under been studied and need to require further attention for understanding consumer behaviour in terms of luxury consumption (Wiedmann et al., 2009; Tsai, 2005). Furthermore, materialism is strongly related to looking for social status among US college students by acquiring goods (Goldsmith et al. 2012; Eastman et al. 1999). Thus, it is proposed that:

H2: Personal value perceptions are related to attitude toward luxury products.

\subsection{Functional Value Perceptions}

Consumers prefer to consume luxury goods for their quality and uniqueness value besides their social and personal value perceptions (Shukla, 2012; Wiedmann et al., 2009). The price of product is also frequently used for prestige by consumers (Shukla, 2012; Brucks et al., 2000). In the matter of luxury, it is highlighted that quality and price of luxury goods go hand in hand (Shukla, 2012; Wiedmann et al., 2007). There is a positive relationships between price and quality in meta-analysis study of Rao and Monroe, (1989). Therefore, it is an important information for luxury brands because in general luxury brands are more expensive than regularly consumed brands (Shukla, 2012). Researches also showed that the price of a product can have positive effects on consumers' perceptions in terms of quality (Wiedmann et al., 2007; Erickson and Johansson 1985; Lichtenstein et al. 1988; Tellis and Gaeth 1990). It has been also emphasized that luxury brands have not only price premium but they also generally focus on high quality as well (Shukla, 2012). Therefore, it is hypothesised that;

H3: Functional value perceptions are related to attitude toward luxury products.

\subsection{Consumer Brand Knowledge}

Consumer brand knowledge includes two main components namely; brand awareness and brand image. Brand awareness that has two sub-components; brand recognition and brand recall is one of the key factor that plays an important role in consumer decision-making (Keller, 1993; Ingsa and Mai; 2017) Brand image that is another sub-components of brand knowledge has been defined "as how the brand is perceived by the consumers" (Aaker, 2010; Ingsa and Mai; 2017). Furthermore, the brand image was defined as "a set of associations, usually organized in some meaningful way" (Aaker, 1991, p. 109). Brand image includes different kinds of associations like brand uniqueness, strength of brand associations, and favourability of brand associations and so on (Keller, 1998). The relationship between brand awareness and brand image is anticipated positively whilst analysing the impacts of luxury brand knowledge on the intention of luxury purchase (Keller, 2012; Ingsa and Mai; 2017). Hence, the moderating role of consumer knowledge besides the effects of value perception on the luxury purchase intention will be measured. it is proposed that;

H4a: (moderator) Consumer knowledge is associated with social value perception toward luxury products.

H4b: (moderator) Consumer knowledge is associated with personal value perception toward luxury products.

H4c: (moderator) Consumer knowledge is associated with functional value perception toward luxury products.

H4d: Consumer knowledge is associated toward luxury products. 


\section{DATA AND METHODOLOGY}

The data were collected in Bursa-Turkey using Simple Random Sampling (SRS). In total, 272 respondents have participated in this survey. The city was chosen for this survey because it is the fourth largest city in Turkey and there are many luxury brands stores in Bursa. It is thus consumer have more opportunities to consume luxury than other small cities. Of the respondents, $63.60 \%$ were female and $36.40 \%$ male. They ranged between 18 and $50+$ years old. While $77 \%$ respondents were single, $22 \%$ were married. The average incomes ranging between less than 1300 to more than 7001 Turkish Liras for per month. A majority of the respondents were well-educated, with approximately twothirds (87\%) holding a university degree or above. The questionnaire divided into four parts, the first three parts focus on luxury value perceptions namely; social value with 6 questions, personal value with 7 questions and functional value with 5 questions. The fourth part focused on consumer knowledge with 3 questions and the fifth part focused on luxury purchase intention with 4 questions. Also, the final part focused on demographic details. The items regarding social value perceptions were derived from, (Chattalas and Shukla, 2015; Shukla, 2010; Truong et al., 2008; O'Cass and McEwen, 2004). The personal value items were cited from (Chattalas and Shukla, 2015; Tsai, 2005; Wiedmann et al., 2009), and functional value items were cited from (Chattalas and Shukla, 2015; Tsai, 2005; Voss et al., 2003). The consumer knowledge scale items were used by Kleiser \& Mantel (1994). The fifth part which related to luxury purchase behaviour scale items were cited from (Chattalas and Shukla, 2015; Cronin and Taylor, 1992). A five-point Likert-type format was used with 'strongly disagree' and 'strongly agree' to measure the all items.

Figure 1: The Proposed Model

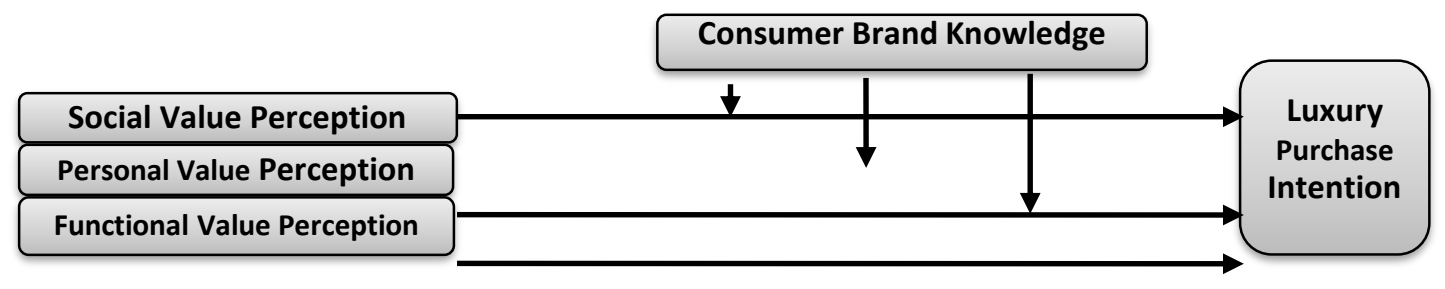

\section{FINDINGS}

For the objectives of this research, SPSS 22.0 and AMOS pocket program was used in order to analyse the data. Thus, firstly, confirmatory factor analysis (CFA) was performed to examine the model fit. Structural equation model (SEM) also performed to test the hypotheses of research. The result of CFA explained that $\chi 2(\mathrm{df}=261)=2.267, \mathrm{P}<0.001$, Goodness-of-fit statistic $(\mathrm{GFI})=0.844$, Comparative fit index $(C F I)=908$ and Root mean square error of approximation (RMSEA) $=0.068$. According to Vinijcharoensri (2016) "The scores of baseline comparison fit indices ranged from between 0.812 and 0.905 , which are close to and exceed 0.9 (recommended point)." Hence, it is implied that all measurement items are reliability and validity.

Table 1: Summary of Hypotheses Test Results

\begin{tabular}{|c|c|c|c|c|}
\hline $\begin{array}{l}\text { Hypothesis } \\
\text { No. }\end{array}$ & Structural Path & $\begin{array}{l}\text { Standardized } \\
\text { Regression } \\
\text { Weight }(\beta)\end{array}$ & $\begin{array}{l}\text { Critical } \\
\text { Ratio (C.R.) }\end{array}$ & Result \\
\hline H1 & Social value $\rightarrow$ Luxury Purchase Intention & $.311^{* *}$ & $5.926 * *$ & Supported \\
\hline $\mathrm{H} 2$ & Personal value $\rightarrow$ Luxury Purchase Intention & $.283 * *$ & $4.959 * *$ & Supported \\
\hline H3 & $\begin{array}{l}\text { Functional value } \rightarrow \text { Luxury Purchase } \\
\text { Intention }\end{array}$ & $.184 * *$ & $3.444 * *$ & Supported \\
\hline $\mathrm{H} 4 \mathrm{a}$ & $\begin{array}{l}\text { Consumer Knowledge (moderator) } \rightarrow \\
\text { Social value and Luxury Purchase Intention }\end{array}$ & .043 & .613 & $\begin{array}{l}\text { Not } \\
\text { Supported }\end{array}$ \\
\hline H4b & $\begin{array}{l}\text { Consumer Knowledge (moderator) } \rightarrow \\
\text { Personal value and Luxury Purchase } \\
\text { Intention }\end{array}$ & $.223 * *$ & $3.407 * *$ & Supported \\
\hline $\mathrm{H} 4 \mathrm{c}$ & $\begin{array}{l}\text { Consumer Knowledge (moderator) } \rightarrow \\
\text { Functional value and Luxury Purchase } \\
\text { Intention }\end{array}$ & $.365^{* *}$ & $5.562 * *$ & Supported \\
\hline H4d & $\begin{array}{l}\text { Consumer Knowledge } \rightarrow \text { Luxury Purchase } \\
\text { Intention }\end{array}$ & $.173^{* *}$ & $3.793 * *$ & Supported \\
\hline
\end{tabular}

${ }^{* *} p<0.001, * p<0.05$, Supported=Significant and Not Supported = Not Significant.

The findings of this research revealed that the value perceptions play an important role on luxury purchase intentions. Therefore, the empirical results of this research overlap with the findings of previous research. However, as mentioned, value perception of luxury brands is different from culture to culture. Asian consumers try to get improve their status using luxury brands and Americans use luxury brands for their self-expression (Phau and Prendergast, 2000). Hence, the moderation role of consumer knowledge is important to examine in terms of value perceptions and luxury purchase intentions. Since, in collectivist society, the aim of the group is more important than the aim of individuals and thus consumer affected by the group member, while in an individualist society, personal preferences take priority and personal prefer independence relationships rather than the collectivist (Soares et al. 2007; Bezzaouia and Joanta, 2016). Belk (1988) 
highlighted that consumers use luxury products for social communications. For this reason, in modern societies, personal and functional values play an important role on luxury purchase intentions. The empirical results of this research also showed that personal and functional value perceptions has effects on luxury purchase intentions. The originality of this research is testing the moderations effect on the relationships between personal and functional value perceptions and luxury purchase intentions. The empirical results showed that consumer knowledge has moderation effects on not only the relationships between personal value perceptions and luxury purchase intention but also the relationships between functional value perception and luxury purchase intention.

\section{CONCLUSION}

To sum up, value perception play an important role on consumer luxury purchase intention on the one hand. On the other hand, consumer knowledge plays a moderating role on the relationships between value perceptions and luxury purchase intetions. In the recent past, consumers who can obtain knowledge easier than before regarding products and can access easly to buy any products of brands from any corner of the world. It is thus easy to compare and chose what they want to buy. It is importamt to take into account value and value perceptions for marketer and so they ought to try to understand value and consumers' value perceptions. Regarding the future research, they should be examined the moderation effect of consumer expertise on luxury purchase intentions. They also could examine the value perceptions in terms of a specific sector.

\section{REFERENCES}

Aaker, D. A. (1991). Managing brand equity: capitalizing on the value of a brand name. Free Press, New York, p. 61,109

Batra, R., Ramaswamy, V., Alden, D., Steenkamp, J. B., Ramachander, S. (2000). Effects of brand local and nonlocal origin on consumer attitudes in developing countries. Journal of Consumer Psychology, vol. 9, no. 2, p. 83-95.

Bearden, W. O., Etzel, M. J. (1982). Reference group influence on product and brand purchase decisions. Journal of Consumer Research, vol. 9, no. 2, p. 183-194.

Belk, R. W. (1988). Possessions and the extended self. Journal of Consumer Research, vol. 15, no. 2, p. 139-168.

Bezzaouia, M., Joanta, A. R. (2016). The relationships between cultural values and consumer motivations for purchasing luxury brands. ECOFORUM, Volume 5, Issue 1 (8). pp. 150-161.

Brucks, M., Zeithaml, V. A., Naylor, G. (2000). Price and brand name as indicators of quality dimensions for consumer durables. Journal of the Academy of Marketing Science, vol. 28 no. 3, p. 359-74.

Bourne, F. S. (1957). Group influence in marketing and public relations. In Some Applications of Behavioral Research, eds. R. Likert and S. P. Hayes, Basil, Switzerland. UNESCO.

Chaudhuri, H. R., Majumdar, S. (2006). Of diamonds and desires: understanding conspicuous consumption from a contemporary marketing perspective. Academy of Marketing Science Review 11: p. 1-18.

Cronin, J., Taylor, S. (1992). Measuring service quality: a re-examination and extension. Journal of Marketing, vol. 56, no. 3, p.55-68.

Dubois, B., Laurent, G. (1994). Attitudes toward the concept of luxury: an exploratory analysis. in Asia-Pacific Advances in Consumer Research. Eds. Siew Meng Leong and Joseph A. Cote, 1, 2, 273-278.

Eastman, J. K., Goldsmith, R. E., Flynn, L. R. (1999). Status consumption in consumer behavior: scale development and validation. Journal of Marketing Theory and Practice, vol. 7, no. 3, p. 41-51.

Erickson, G., Johansson, J. K. (1985). The role of price in multi-attribute product evaluations. Journal of Consumer Research, vol. 12, no. 2, p. 195-199.

Goody, J. (2006). From misery to luxury. Social Science Information, vol. 45, no. 3, p. 341-348.

Goldsmith, R. E., Flynn, L. R., Clark, R. A. (2012). Materialistic, brand engaged and status consuming consumers and clothing behaviours. Journal of Fashion Marketing and Management, vol. 16, no. 1, p. 102-119.

Ingsa, K., Mai, L. W. (2017). The influence of brand knowledge on the intention to purchase personal luxury products. International Marketing Trends Conference.

Kapferer, J. N. (1997). Managing luxury brands. Journal of Brand Management, vol. 4, no. 4, p. 251-260.

Keller, K. L. (1993). Conceptualizing, measuring, and managing customer-based brand equity. Journal of Marketing, 57, pp.1-22.

Keller, K. L., Apéria, T., Georgson, M. (2012). Strategic brand management. A European perspective. 2nd ed. Essex: Pearson.

Kleiser, S. B., Mantel, S. P. (1994). The dimensions of consumer expertise: a scale development. In: Achrol R, Mitchell A, editors. AMA Summer Educators' Proceedings 5. Chicago: American Marketing Association; p. 20-6.

Lichtenstein, D. R., Bloch, P. H., Black, W. C. (1988). Correlates of price acceptability. Journal of Consumer Research, vol. 15, no. 2, p. 243252. 
Nueno, J. L., Quelch, J. A. (1998). The mass marketing of luxury. Business Horizons, 39 (6), 61-68.

O’Cass, A., McEwen, H. (2004). Exploring consumer status and conspicuous consumption. Journal of Consumer Behaviour, Vol. 4, No. 1, pp.25-39.

Patsiaouras, G., Fitchett, J. A. (2012). The evolution of conspicuous consumption. Journal of Historical Research in Marketing, Vol. 4 No. 1, 2012 pp. 154-176.

Phau, I., Prendergast, G. (2000). Consuming luxury brands: the relevance of the 'Rarity Principle. Brand Management, 8 (2), pp.122-138.

Rao, M. (1988). The moderating effect of prior knowledge on cue utilization in product evaluations. The Journal of Consumer Research, vol. 15 , no. 2, p. 253-264.

Shukla, P., Chattalas, M. (2015). Impact of value perceptions on luxury purchase intentions: a developed market comparison. Luxury Research J., vol. 1, no. 1, p. 40-57.

Shukla, P. (2012). The influence of value perceptions on luxury purchase intentions in developed and emerging markets. International Marketing Review, vol. 29, no. 6, p. 574-596.

Shukla, P., Purani, K. (2011). Comparing the importance of luxury value perceptions in cross-national contexts. Journal of Business Research, vol. 65, no. 10, p. 1417-24.

Singh, J. (1995). Measurement issues in cross-national research. Journal of International Business Studies, vol. 26, no. 3, p. 597-619.

Soares, A. M., Farhangmehr, M., Shoham, A. A. A. (2007). Hofstede's dimensions of culture in international marketing studies. Journal of Business Research, 60, 277-284

Souiden, N., M'Saad, B., Pons, F. (2011). A cross-cultural analysis of consumers' conspicuous consumption of branded fashion accessories. Journal of International Consumer Marketing, 23: p. 329-343.

Tellis, G. J., Gaeth, G. J. (1990). Best value, price-seeking, and price aversion: the impact of information and learning on consumer choices. Journal of Marketing, vol. 54, no.2, p. 34-45.

Truong, Y., Simmons, G., McColl, R., Kitchen, P. J. (2008). Status and conspicuousness - are they related? Strategic marketing implications for luxury brands. Journal of Strategic Marketing, Vol. 16, No. 3, pp.189-203.

Tsai, S. P. (2005). Impact of personal orientation on luxury-brand purchase value. International Journal of Market Research, Vol. 47 No. 4, pp. 177-206.

Tynan, C., McKechnie, S., Chhuon, C. (2010). Co-creating value for luxury brands. Journal of Business Research, vol. 63, no. 11, pp. $1156-63$. Vigneron, F., Johnson, L. W. (2004). Measuring perceptions of brand luxury. Journal of Brand Management, vol. 11 no. 6, pp. $484-508$.

Voss, K. E., Grohmann, B., Spangerbeng, E. R. (2003). Measuring the hedonic and utilitarian dimensions of consumer attitude. Journal of Marketing Research, vol. 40, no. 3, p. 310-320

Wiedmann, K. P., Hennigs, N., Siebels, A. (2007). Measuring consumers' luxury value perception: a cross-cultural framework. Academy of Marketing Science Review. Volume 2007 no. 7 Available: http://www.amsreview.org/articles/wiedmann07-2007.pdf

Wiedmann, K. P., Hennigs, N., Siebels, A. (2009). Value-based segmentation of luxury consumption behaviour. Psychology and Marketing, Vol. 26 No. 7, pp. 625-51.

Zeithaml, V. A. (1988). Consumer perceptions of price, quality, and value: a means-end model and synthesis of evidence. Journal of Marketing, vol. 52, no. 3, pp. 2-22. 